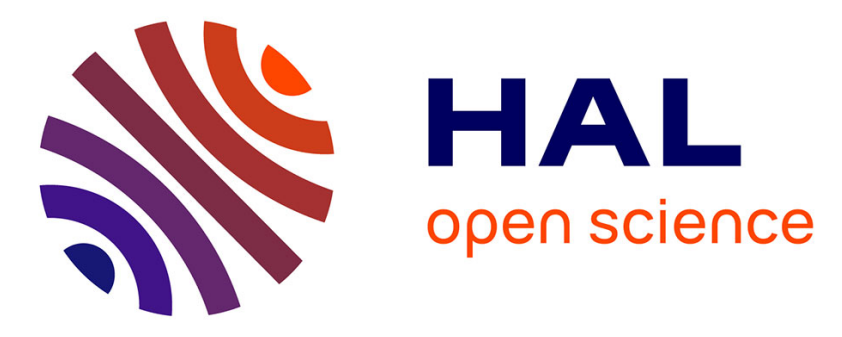

\title{
Automatic ice-cream characterization by impedance measurements for optimal machine setting
} Marco Grossi, Massimo Lanzoni, Roberto Lazzarini, Bruno Riccò

\section{To cite this version:}

Marco Grossi, Massimo Lanzoni, Roberto Lazzarini, Bruno Riccò. Automatic ice-cream characterization by impedance measurements for optimal machine setting. Measurement - Journal of the International Measurement Confederation (IMEKO), 2012, 45 (7), pp.1747-1754. 10.1016/j.measurement.2012.04.009 . hal-01276540

\section{HAL Id: hal-01276540 \\ https://hal.science/hal-01276540}

Submitted on 25 Feb 2016

HAL is a multi-disciplinary open access archive for the deposit and dissemination of scientific research documents, whether they are published or not. The documents may come from teaching and research institutions in France or abroad, or from public or private research centers.
L'archive ouverte pluridisciplinaire HAL, est destinée au dépôt et à la diffusion de documents scientifiques de niveau recherche, publiés ou non, émanant des établissements d'enseignement et de recherche français ou étrangers, des laboratoires publics ou privés. 
1 Automatic Ice-Cream Characterization by Impedance Measurements for Optimal Machine

2 Setting

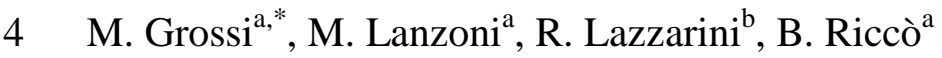

$5 *$ Corresponding author: marco.grossi8@unibo.it, Tel. 0039-0512093082, Fax 0039-0512093785

6 a Department of Electronic Engineering (D.E.I.S.), University of Bologna, Bologna, Italy

7 b Carpigiani Group, Anzola Emilia, Bologna, Italy

\section{Abstract}

10 Electrical characterization of products is gaining increasing interest in the food industry for quality

11 monitoring and control. In particular, this is the case in the ice-cream industry, where machines

12 dedicated to store ice-cream mixes are programmed "ad hoc" for different groups of products. To

13 this purpose, the present work shows that essential product classification (discrimination between

14 milk based and fruit based ice-cream mixes) can be done by means of a technique based on the

15 measurements of non-linear response in the electrical behavior of the electrode-electrolyte interface.

16 The addition of $\mathrm{pH}$ measurements allows to further reach the three parts classification occasionally

17 required for advanced applications. The proposed idea is validated by means of measurements on 1821 ice-cream mixes, different for producers and composition.

Keywords: food quality control; ice-cream mix; industrial sensors; electrical impedance 21 spectroscopy; electrode-electrolyte interface.

\section{1. Introduction}

24 While in the early stage of the food industry the competition was mainly focused on costs, today 25 product quality and safety are a primary concern. Consequently, products are routinely screened for 
important organoleptic characteristics (such as smell, aroma, color,...) as well as to guarantee that microbial content is below the maximum allowed threshold concentration.

In the past, all tests were performed off-line, i.e. a limited number of product samples were sent to a laboratory to be tested and the results became available with long delays. Today, automated production methods with integrated monitoring systems allow much faster response and the possibility to screen all the products with non destructive measurements.

In this context, food characterization by means of electrical measurements easily implementable in automatic form plays a crucial role and a number of significant examples can be mentioned: detection of water and lipid content in meat [1], dilution factor in apple puree [2], determination of $\mathrm{pH}$, acidity and hardness in yogurt [3], quality control of vegetable oils [4]. In particular, as far as concentration in milk [10] and ice-cream [11][12][13]. discrimination is that between creamy and frozen yogurt products. At present, specific machine parameters for these three ice-cream groups (but often differences are considered only among milk and fruit based mixes) are set manually: hence an operator is needed every time the stored ice-cream mix type is changed. Instead, if the product type could be 
discriminated by means of an electronic system embedded in the machine, such an intervention would be no longer necessary, with significant advantages in terms of costs, time and error reduction.

Electrical Impedance Spectroscopy (EIS) is often used for electrical characterization of food products. In EIS the sample under test is placed in direct contact with electrodes and stimulated with a sinusoidal test voltage $V_{i n}(t)=V_{M} \operatorname{sen}(\omega t)=V_{M} \operatorname{sen}(2 \pi f t)$ with fixed amplitude $\mathrm{V}_{\mathrm{M}}$ in a definite range of frequencies. The current $\mathrm{I}_{\text {in }}(\mathrm{t})$ through the electrodes due to the test signal is measured and, if the system electrode-electrolyte can be considered linear (i.e. if $V_{\text {in }}(t)$ is the weighted sum of several signals, then $I_{i n}(t)$ is the weighted sum of the system response to each of the signals), the complex impedance $Z$ can be calculated as $Z=|Z| e^{j \operatorname{Arg}(Z)}=V_{\text {in }}(j \omega) / I_{\text {in }}(j \omega)$, where $V_{\text {in }}(j \omega), I_{i n}(j \omega)$ are the Steinmetz phasors of the sinusoidal signals $V_{\text {in }}(t)$ and $I_{\text {in }}(t)$ respectively, $|Z|$ is the impedance modulus and $\operatorname{Arg}(\mathrm{Z})$ the impedance phase. The acquired spectra can be represented with different graph types, such as Bode plots, where $|\mathrm{Z}|$ and $\operatorname{Arg}(\mathrm{Z})$ are plotted as function of the test signal frequency, or Nyquist plots where the impedance imaginary component $\operatorname{Im}(Z)=|Z| \operatorname{sen}(\operatorname{Arg}(Z))$ is plotted vs. the real component $\operatorname{Re}(Z)=|Z| \cos (\operatorname{Arg}(Z))$ for different frequencies.

EIS data for a set of samples, featuring different values of the parameter under study, are analyzed in order to extract a relation between the measured electrical parameters and the product parameter. The electrochemical system composed of sample under test and electrodes is, however, a non-linear system [14]. To effectively apply EIS, the test signal must feature small amplitude $\mathrm{V}_{\mathrm{M}}$ so to confine the system in a pseudo-linear region.

3 Nevertheless, study of the electrical response in the non-linear region (using larger amplitude excitation potentials) can extend the knowledge and provide additional data on the product.

In this paper ice-cream mixes, different for composition and producers, are tested both with EIS and in the non-linear region to achieve the products discrimination needed for practical purpose. 


\section{Experimental approach}

79 The objective of the study is to discriminate a set of ice-cream mixes, different for composition and producers, in two different groups (milk based and fruit based mixes) with eventually a second level

81 discrimination of the milk based products in creamy mixes and frozen yogurts. To this purpose, the whole set of ice-cream mixes has been subjected to the following tests:

1) EIS measurements with a sinusoidal test signal of amplitude $100 \mathrm{mV}$ in the frequency range 20 $\mathrm{Hz}$ to $10 \mathrm{KHz}$. The acquired spectra have been analyzed to validate the electrical model and the model parameters estimated with "ad hoc" developed LabVIEW (National Instruments, Austin, USA) programs using least squares error method.

2) The electrical response in the non-linear region has been studied by stimulating the sample with a sinusoidal test signal of frequency $20 \mathrm{~Hz}$ and amplitude in the range $10 \mathrm{mV}$ to $2 \mathrm{~V}$. The measured data has been fitted to a non-linear empirical model (described in section 5) and the model parameters calculated by Levenberg-Marquardt algorithm (LMA). LMA is an iterative technique that locates the minimum of a multivariate function that is expressed as the sum of squares of nonlinear real valued functions. The algorithm needs initial guess for the function parameters to be used as starting values for the iterative procedure. It has been implemented using built-in project libraries from LabVIEW.

3) $\mathrm{pH}$ measurements have been performed by means of a Crison micropH 2000 (Crison Instruments, South Africa). The instrument has been calibrated before each measure using standard buffer solutions featuring $\mathrm{pH} 4$ and 7 respectively. Statistical analysis has been carried out with PHStat (Prentice Hall statistical add-on for Microsoft EXCEL). Student t-test assuming unequal variances and non-parametric Mann Whitney test have been performed to find significant differences in the measured mean values of measured parameters (confidence level of $95 \%$ ). Multiple regression analysis has been carried out using the Best-Subset procedure to investigate the correlation between $\mathrm{pH}$ values and measured electrical parameters. 


\section{Measurement setup}

105 All the measurements of this work are made with Lab instruments.

106 The setup used for the experiments is illustrated in Fig. 1 (a): the product samples are incubated in a 107 thermal chamber WTC Binder providing the target temperature with an uncertainty of $0.1{ }^{\circ} \mathrm{C}$. 108 Measures have been carried out at two different temperatures $\left(4{ }^{\circ} \mathrm{C}\right.$ and $\left.35{ }^{\circ} \mathrm{C}\right)$. The two 109 temperatures have been chosen according to the following rules: $4{ }^{\circ} \mathrm{C}$ is the standard temperature 110 the ice-cream mixes are stored while $35^{\circ} \mathrm{C}$ is the temperature used in a microbial biosensor system 111 recently developed by the authors [13]. Thus, the choice has been made with the idea of a future 112 implementation in industrial environment as a sensor integrated in the tank of the storing machine $113\left(4{ }^{\circ} \mathrm{C}\right)$ or in a separate chamber controlled with the embedded biosensor system $\left(35^{\circ} \mathrm{C}\right)$. However, 114 the measures at $4{ }^{\circ} \mathrm{C}$ resulted in poor repeatability (see Supplementary Material for more 115 information). This can be related to the fact that at $4{ }^{\circ} \mathrm{C}$ the ice-cream mixes are in a semi-viscous 116 frozen state and also small temperature variations can produce relatively large changes in the 117 product structure. Thus, in the following, only measures at $35{ }^{\circ} \mathrm{C}$ are discussed. Electrical 118 characteristics of the sample $(|\mathrm{Z}|$ and $\operatorname{Arg}(\mathrm{Z}))$ are measured with an LCR meter Agilent E4980A, 119 controlled via USB interface by a PC system that is also used to acquire measured data and further 120 data processing. The sample under test is placed in a $10 \mathrm{ml}$ container with cap shaped stainless steel 121 electrodes. Two types of sensors are used: sensor A (Fig. 1 (b)) consists of two electrodes while sensor B (Fig. 1 (c)) has four electrodes that are shorted together in couples as shown in the figure.

123 The difference between the two sensors is related to the generated electric field. Both sensor 124 geometries have been simulated using the software Comsol Multiphysics v4 (Comsol Inc, Palo 125 Alto, USA). The electric field distribution is also shown in Fig. 1 (b) and (c). Sensor B is 126 characterized by more homogeneous electric field with higher values than sensor A for both the 127 field and its gradient. All the ice-cream mixes have been tested with both types of sensors.

\section{Ice-cream mixes}


130 Measurements have been performed on a set of 21 ice-cream mixes, different for ingredients and

131 producers, which can be classified in two main categories: fruit and milk based. The latter category 132 can be further divided in creamy and frozen yogurt products. The ice-cream mixes as well as the 133 measured $\mathrm{pH}$ values are listed in Table 1: those from 1 to 14 are milk based ("creamy" ones from 1 134 to 10 and frozen yogurt mixes from 11 to 14 ), while those from 15 to 21 are fruit based. The 135 composition of the 21 ice-cream mixes is reported in the Supplementary Material.

136 The ice-cream mixes production has been carried out using a Carpigiani Pastomaster RTL machine 137 to prepare, pasteurize and age ice-cream mixes. The basic steps in the manufacturing are as follows: 138 - Mixing of ingredients (i.e. mixing powder with water in the tank of the pasteurizer).

139 - Pasteurization.

140 - Cooling to $4^{\circ} \mathrm{C}$.

141 - Aging at $4^{\circ} \mathrm{C}$ for 10 hours.

\section{Electrical circuit model}

144 EIS has been carried out with a sinusoidal test signal of amplitude $\left(\mathrm{V}_{\mathrm{M}}\right) 100 \mathrm{mV}$ on the frequency range $20 \mathrm{~Hz}$ to $10 \mathrm{KHz}$ (logarithmically spaced). Preliminary measurements were performed with the LCR meter full frequency range $(20 \mathrm{~Hz}$ to $2 \mathrm{MHz}$ ). However, since the high frequency response resulted in higher noise-to-signal ratio and lower repeatability (see the Supplementary Material for more details) only the frequency range $20 \mathrm{~Hz}$ to $10 \mathrm{KHz}$ is discussed. Fig. 2 (a) shows the Nyquist plot for three different samples measured with sensor A: the samples are two milk based mixes (\#3 and \#9 in Table 1) characterized by different fats content and a fruit based mix (\#19 in Table 1). As

151 can be seen a linear relation exists between $\operatorname{Im}(Z)$ and $\operatorname{Re}(Z)$.

152 The electrical model used to fit the data in the investigated frequency range is shown in Fig. 2 (b): it 153 is composed of a resistance $\mathrm{R}_{\mathrm{m}}$ (accounting for the resistance of both the sample and the interface) 154 and a constant phase element CPE (resulting from the essentially capacitive component due to the 155 interface electrode-medium) in series. Since the ice-cream is an unstructured material no distinct 
dispersion exists within the radiofrequency range up to several MHz. The sample impedance is thus purely resistive while the reactive component is essentially due to the electrode interface. The impedance of CPE is described by two parameters ( $\mathrm{Q}$ and $\alpha$ ) where $\mathrm{Q}$ represents the double layer capacitance, while $\alpha$ accounts for the non ideal electrode-medium interface (the case $\alpha=1$ refers to an ideal capacitance). The reason for using a CPE instead of a linear capacitor is the non ideal behavior of electrode interface [15]. Moreover, the calculated impedance using a linear capacitor results in $\operatorname{Re}(Z)$ to be independent of frequency, contrary to the Nyquist plot of Fig. 2 (a).

With the model of Fig. 2 (b) it is:

$Z=R_{m}+Z_{C P E}=R_{m}+\frac{1}{Q(j \omega)^{\alpha}}=R_{m}+\frac{e^{-j \frac{\pi}{2} \alpha}}{Q \omega^{\alpha}}=R_{m}+\frac{\cos \left(\frac{\alpha \pi}{2}\right)}{Q \omega^{\alpha}}-j \frac{\sin \left(\frac{\alpha \pi}{2}\right)}{Q \omega^{\alpha}}$

Thus:

$\operatorname{Re}(Z)=R_{m}-\operatorname{ctg}\left(\frac{\alpha \pi}{2}\right) \times \operatorname{Im}(Z)$

The parameters $\mathrm{R}_{\mathrm{m}}, \mathrm{Q}$ and $\alpha$ are determined by best fitting the experimental data with the proposed electrical model for all ice-cream mixes and both sensors. The determination coefficient $\mathrm{R}^{2}$ between experimental and fitted data is found to be never lower than 0.998 , thus validating the electrical model. The parameter $\alpha$ is found to be almost independent on the measured samples with values in the range $0.73-0.79$ for both sensors. Fig. 3 shows the experimental data $(|Z|$ and $\operatorname{Arg}(Z))$ as well as the curves fitting the model in the case of the vanilla flavored Angelito mix (\# 9 in Table 1) and sensor A.

The electrical characterization in the non-linear region for the electrode-medium system is investigated measuring $|\mathrm{Z}|$ with a sinusoidal voltage signal of fixed frequency and $\mathrm{V}_{\mathrm{M}}$ in the range $10 \mathrm{mV}$ to $2 \mathrm{~V}$ (with logarithmic spacing). Fig. 4 shows $|\mathrm{Z}|_{10 \mathrm{mV}-}|\mathrm{Z}|$ vs. $\mathrm{V}_{\mathrm{M}}$ (logarithmic scale) for different frequencies in the case of the Angelito mix (\# 9 in Table 1) and sensor A. The value of $|\mathrm{Z}|$ is almost constant for small signal amplitude (i.e. $\mathrm{V}_{\mathrm{M}} \ll \mathrm{V}_{\mathrm{MT}}$, with $\mathrm{V}_{\mathrm{MT}}$ never lower than $200 \mathrm{mV}$ ), while for higher values of $\mathrm{V}_{\mathrm{M}}$, it decreases linearly with $\log _{10}\left(\mathrm{~V}_{\mathrm{M}}\right)$, thus producing an increase of 
$|\mathrm{Z}|_{10 \mathrm{mv}-}|\mathrm{Z}|$. The results clearly indicate that increasing the test signal frequency results in an increase

181 of the cut-off amplitude $\mathrm{V}_{\mathrm{MT}}$ and a decrease of the slope in the non-linear region.

182 In order to characterize the electrical response in the non-linear region for the tested products, the 183 curves have been fitted with the empirical model $|Z|=|Z|_{10 m V}+\beta_{1} \cdot \log _{10}\left(1+\left(V_{M} / V_{M T}\right)^{\beta_{2}}\right)$, where $184|\mathrm{Z}|_{10 \mathrm{mV}}$ is the value of $|\mathrm{Z}|$ for small signal amplitude (i.e. linear response region), $\mathrm{V}_{\mathrm{MT}}$ the cut-off 185 amplitude (separating the linear from non-linear region) while $\beta_{1}$ and $\beta_{2}$ are empiric parameters 186 used to fit the curve. Fitting procedure has been carried out by LMA. The iterative algorithm has 187 been run with the following initial guess for parameters $|\mathrm{Z}|_{10 \mathrm{mV}}=300 \beta_{1}=0.6 \mathrm{~V}_{\mathrm{MT}}=600 \beta_{2}=11$ for all 188 ice-cream mixes and both sensors. Fitting procedure resulted in high determination coefficient $\left(\mathrm{R}^{2}>\right.$ 189 0.99), thus validating the empirical model. The slope $\lambda$ in the non-linear region has been estimated 190 with the following procedure: when $V_{M} \gg V_{M T}$ the empirical model function can be simplified as $|Z| \approx|Z|_{10 m V}+\beta_{1} \cdot \log _{10}\left(V_{M} / V_{M T}\right)^{\beta_{2}}=|Z|_{10 m V}+\beta_{1} \cdot \beta_{2} \cdot \log _{10}\left(V_{M} / V_{M T}\right)$, thus:

$$
\lambda=\frac{\partial|Z|}{\partial \log _{10}\left(V_{M} / V_{M T}\right)} \approx \beta_{1} \cdot \beta_{2}
$$

193 The model parameters are estimated by LMA for $\mathrm{f}=20 \mathrm{~Hz}$, since, as shown in Fig. 4, non-linear response is stronger (higher values of $\lambda$ ) at lower frequencies. However, only values of $\lambda$ are reported in section 6 , since the other parameters exhibit lower correlation with the ice-cream mixes groups.

\section{Results and discussion}

\subsection{Electrical impedance spectroscopy}

200 The ice-cream mixes have been tested following the procedures described in section 2 and section

201 5. The experimental results are illustrated in Fig. 5. Statistical analysis of the presented data indicates that significant differences exist between fruit based and both creamy and frozen yogurt mixes in the case of $R_{m}$. Fruit based mixes are generally characterized by higher values of $R_{m}$ than 
milk based mixes. In particular, mean values of $R_{m}$ for fruit based mixes are $838.9 \Omega$ and $276.2 \Omega$

205 for sensor A and sensor B, respectively. Instead, the corresponding values for creamy mixes are $206328.7 \Omega$ and $95.3 \Omega$, while for frozen yogurt products these values are $406.9 \Omega$ and $74.1 \Omega$. 207 However, a small number of fruit based mixes (banana and kibana based mixes, \# 17 and 20, 208 respectively) exhibit values of $\mathrm{R}_{\mathrm{m}}$ comparable with those of the milk based group, due to the 209 presence of potassium salts that greatly enhances conductivity.

210 Conductivity for the dairy products is mainly related to fats and salt content: higher concentration of 211 milk fats results in higher values of $R_{m}$, while the increase in salt concentration leads to resistance 212 decrease, as can be clearly seen comparing the values of $\mathrm{R}_{\mathrm{m}}$ for mixes 1 and 2 . However, 213 comparison between mixes 2 and 3 clearly indicates that pasteurization temperature also plays a 214 role in the measured electrical characteristics, since the same mix subjected to high temperature 215 pasteurization cycle $\left(85{ }^{\circ} \mathrm{C}\right)$ results in a higher value for $\mathrm{R}_{\mathrm{m}}$ than that of the mix pasteurized at 216 lower temperature $\left(65^{\circ} \mathrm{C}\right)$. On the other hand, it is known that differences in pasteurization 217 temperature can significantly alter some organoleptic characteristics of the product: for instance, 218 [16] showed that ice-cream mixes pasteurized with high thermal cycle (between $75{ }^{\circ} \mathrm{C}$ and $82{ }^{\circ} \mathrm{C}$ ) 219 exhibit lower fat clumping, viscosity and freezing time, and higher protein stability. To investigate 220 if repeated pasteurization cycles can effectively alter the product electrical characteristics, mix 2 has 221 been subjected to low temperature pasteurization cycles $\left(65^{\circ} \mathrm{C}\right)$ at time intervals of 1 day and the 222 electrical parameters have been measured after each cycle : no correlation was observed between 223 the electrical parameters and the number of pasteurization cycles, thus showing that only thermal 224 cycling with high temperature significantly affects the product characteristics, while repeated 225 cycling at lower temperature produces no detectable change.

226 As far as values of $\mathrm{Q}$ are considered (expressed as $10^{6} \mathrm{~s}^{\alpha} / \Omega$ ), fruit based and frozen yogurt mixes 227 exhibit values significantly higher than those of creamy mixes: mean values of 66.6 and 64.6 for 228 sensor A and 121.9 and 114.7 for sensor B as compared to 51.5 and 93.5 for creamy mixes. Once 
again, overlapping values of Q exist among different groups and no significant difference between

230 frozen yogurt and fruit based mixes is detected.

231 On the whole, the results shown in Fig. 5 indicate that EIS does not allow to reliably discriminate 232 milk and fruit based ice-creams.

\subsection{Electrical response in the non-linear region}

235 As already anticipated, searching for a method to reliably discriminate the different products groups, the electrical response in the non-linear region has been investigated.

Fig. 6 shows the values of $\lambda$ in the non-linear region for all mixes and both sensors. As can be seen fruit based mixes are all characterized by values of $\lambda$ lower than the other groups: this is particularly evident for sensor B, that is able to reliably discriminate fruit based mixes, while with sensor A the gap between values of $\lambda$ for the different groups is smaller, thus leading to less accurate detection and possible misclassification of ice-cream mixes with high milk fat content. In the case of frozen yogurt, the values of $\lambda$ are not significantly different from those of creamy mixes: thus the two groups cannot be discriminated with this parameter.

244 These results clearly indicate that measurements of $\lambda$ provides a reliable method to automatically 245 discriminate milk based from fruit based ice-creams, as required for automatic machine setting 246 (with sensor B resulting in larger differences for the values of $\lambda$ of the two groups and thus more 247 reliable discrimination). The distinction between creamy and frozen yogurt mixes cannot be 248 performed by analyzing values of $\lambda$ (as can be seen in Fig. 6).

249 If required, reliable discrimination between creamy and frozen yogurt products can be achieved by 250 measuring the mix $\mathrm{pH}$. As can be seen in Table 1 , creamy mixes are almost neutral $(\mathrm{pH}>6)$ while 251 frozen yogurt mixes exhibit $\mathrm{pH}$ values in the range 4.5 to 5. Fruit based products, instead, have $\mathrm{pH}$ 252 values in the range 2 to 5, with few exceptions, such as \# 16 in Table 1 , featuring $\mathrm{pH}=6$, due to a 253 content of organic acid much lower than other fruit based mixes [17]. 
Since all the three product groups of interest can be discriminated by means of combined measurements of $\mathrm{pH}$ and electrical parameters, correlation between electrical parameters and $\mathrm{pH}$ has been studied.

\subsection{Correlation between electrical and pH measures}

259 The correlation between measured electrical parameters $\mathrm{R}_{\mathrm{m}}, \mathrm{Q}$ and $\lambda$ for both types of sensors and $260 \mathrm{pH}$ has been investigated, and the results are presented in Supplementary Material, where the values 261 of $\mathrm{pH}$ are plotted versus the corresponding electrical parameter for all ice-cream mixes and both sensors. The results indicate poor correlation between $\mathrm{pH}$ and the corresponding electrical parameter, especially $R_{m}$, where a determination coefficient as low as 0.216 and 0.17 (for sensor $A$ and $\mathrm{B}$ respectively) is found.

265 Better results are obtained for the correlation of $\mathrm{pH}$ with $\lambda(0.444$ and 0.489$)$ and $\mathrm{Q}(0.533$ and 0.492). However, the determination coefficient never higher than 0.533 is not satisfactory, preventing a reliable estimate of $\mathrm{pH}$ with electrical measures. Multiple regression analysis has been carried out to test if expressing $\mathrm{pH}$ as linear function of more than a single electrical parameter significantly increases the correlation. The best results are obtained (for both sensors) by using Q and $\lambda$ as independent variables, namely: $\mathrm{pH}=\mathrm{b}_{0}+\mathrm{b}_{1} * \mathrm{Q}+\mathrm{b}_{2} * \lambda$, where $\mathrm{b}_{0}, \mathrm{~b}_{1}$ and $\mathrm{b}_{2}$ are numerical parameters. In this way, however, the determination coefficient $\mathrm{R}^{2}$ (corrected for the use of multiple variables) increases only slightly in the case of the data obtained with sensor A (0.621) while no improvement is found in the case of sensor B.

274 Thus, $\mathrm{pH}$ can not be reliably inferred by electrical parameters $\mathrm{R}_{\mathrm{m}}, \mathrm{Q}$ and $\lambda$.

275 The overall results from the study are presented in Table 2. Regarding the primary discrimination between milk based and fruit based mixes, although the resistive component of the impedance $\mathrm{R}_{\mathrm{m}}$ is characterized by statistical significantly different values for the two groups, the discrimination is not reliable due to few fruit based mixes characterized by higher conductivity. On the contrary, the parameter $\lambda$ measured in the non-linear region can provide reliable discrimination between the two 
groups (in particular using sensor B). The second level discrimination of milk based mixes in 281 creamy mixes and frozen yogurts can be reliably achieved by $\mathrm{pH}$ measure, while electrical parameter Q (although characterized by significantly different values for the two subgroups) doesn't provide a reliable solution due to overlapping values between the two subgroups.

\section{Conclusions}

286 In this paper the possibility to discriminate different groups of ice-cream mixes by means of 287 electrical measurements, so as to allow automatic setting of product storing machines has been studied. To this purpose, a distinction between milk and fruit based products is essential, and sufficient for most practical purposes. Furthermore, within the first category it is sometimes required to discriminate frozen yogurt products from the remaining (creamy) ice-creams.

291 To reach the goal, this work has investigated the possibility to use Electrical Impedance 292 Spectroscopy (performed by stimulating the sample with a sinusoidal test signal of amplitude 100 $\mathrm{mV}$ and frequency in the range $20 \mathrm{~Hz}$ to $10 \mathrm{KHz}$ ) showing that it does not provide a reliable 294 solution.

295 Instead, electrical characterization in the non-linear region (obtained with a sinusoidal test signal of 296 frequency $20 \mathrm{~Hz}$ and amplitude in the range $10 \mathrm{mV}$ to $2 \mathrm{~V}$ ) is shown to do the work as far as the 297 basic distinction between milk and fruit based products is concerned.

298 As the second level distinction within the first category, it can be done measuring the $\mathrm{pH}$ values of 299 the products, which is lower for frozen yogurt than for the creamy mixes.

300 Although the experiments of this work have been carried out with Lab instruments, measurements 301 of electrical response in the non-linear region can be implemented in the form of a low-cost 302 electronic board, and this holds also for $\mathrm{pH}$ determination. Thus, the present work provides the 303 fundamentals for a possible future development of an embedded system that can open the road for 304 fully automatic industrial ice-cream machines. 


\section{Acknowledgements}

307 The authors thank Dr. Anna Pompei (Department of Pharmaceutical Sciences, University of 308 Bologna) for $\mathrm{pH}$ measurements and many helpful discussions.

\section{References}

[1] M. Chanet, C. Riviere, P. Eynard, Electric impedance spectrometry for the control of 313 manufacturing process of comminuted meat products. Journal of Food Engineering 42 (1999) 153$314 \quad 159$

[2] R. Zywica, G. Pierzynowska-Korniak, J. Wojcik, Application of food products electrical model parameters for evaluation of apple puree dilution. Journal of Food Engineering 67 (2005) 413-418

[3] Y. Kitamura, K. Toyoda, B. Park, Electric impedance spectroscopy for yogurt processing. Food

Science and Technology Research 6 (4) (2000) 310-313

[4] A. Cataldo, E. Piuzzi, G. Cannazza, E. De Benedetto, L. Tarricone, Quality and anti-adulteration control of vegetable oils through microwave dielectric spectroscopy. Measurement 43 (2010) 10311039

[5] M.F. Mabrook, M.C. Petty, Application of electrical admittance measurements to the quality

[6] J. Yang, M. Huang, J. Peng, J. Shi, Rapid determination of moisture content in milk powder by microwave sensor. Measurement (2010) doi: 10.1016/j.measurement.2010.08.007 
332 [7] B.A. Lawton, R. Pethig, Determining the fat content of milk and cream using ac conductivity 333 measurements. Measurement Science and Technology 4 (1993) 38-41

335 [8] E. Norberg, H. Hogeveen, I.R. Korsgaard, N.C. Friggens, K.H.M.N. Sloth, P. Lovendahl, 336 Electrical conductivity of milk : ability to predict mastitis status. Journal of Dairy Science 87 (2004) $337 \quad 1099-1107$

339 [9] F.J. Ferrero, G. Grillo, M.A. Perez, J.C. Anton, J.C. Campo, Design of low cost mastitis detector 340 in cows by measuring electrical conductivity of milk. IEEE Instrumentation and Measurement 341 Technology Conference (2002) 375-378

343 [10] C.J. Felice, R.E. Madrid, J.M. Olivera, V.I. Rotger, M.E. Valentinuzzi, Impedance 344 microbiology: quantification of bacterial content in milk by means of capacitance growth curves. 345 Journal of Microbiological Methods 35 (1999) 37-42

347 [11] M. Grossi, M. Lanzoni, A. Pompei, R. Lazzarini, D. Matteuzzi, B. Riccò, Detection of 348 microbial concentration in ice-cream using the impedance technique. Biosensors \& Bioelectronics $34923(2008) 1616-1623$

[12] M. Grossi, A. Pompei, M. Lanzoni, R. Lazzarini, D. Matteuzzi, B. Riccò, Total bacterial count 352 in soft-frozen dairy products by impedance biosensor system. IEEE Sensors Journal 9 (10) (2009) $353 \quad 1270-1276$ 
359 [14] E.T. McAdams, A. Lackermeier, J.A. McLaughlin, D. Macken, The linear and non-linear 360 electrical properties of the electrode-electrolyte interface. Biosensors \& Bioelectronics 10 (1995) $361 \quad 67-74$

\begin{tabular}{llc}
\hline$\#$ & Ice-cream mix & pH \\
\hline
\end{tabular}

363 [15] W.H. Mulder, J.H. Sluyters, T. Pajkossy, I. Nyikos, Tafel current at fractal electrodes. 364 Connection with the admittance spectra. Journal of Electroanalytical Chemistry 285 (1990) 103$365 \quad 115$

[16] L.R. Dowd, E.O. Anderson, Study of short-time-high-temperature pasteurization of ice cream 368 mix. Journal of Dairy Science 26 (1) (1943) 37-46

[17] S. Gurrieri, L. Miceli, C.M. Lanza, F. Tommaselli, R.P. Bonomo, E. Rizzarelli, Chemical 371 characterization of sicilian prickly pear (opuntia ficus indica) and perspectives for the storage of its 372 juice. Journal of Agricultural and Food Chemistry 48 (2000) 5424-5431 


\begin{tabular}{|c|c|c|}
\hline 1 & Soft serve mix (low fat content - pasteurization at $65^{\circ} \mathrm{C}$ ) & 6,2 \\
\hline 2 & Soft serve mix (high fat content - pasteurization at $65^{\circ} \mathrm{C}$ ) & 6,3 \\
\hline 3 & Soft serve mix (high fat content - pasteurization at $85^{\circ} \mathrm{C}$ ) & 6,2 \\
\hline 4 & Egg based ice-cream mix & 6,6 \\
\hline 5 & Fiordilatte ice-cream mix & 6,6 \\
\hline 6 & Chocolate ice-cream mix & 7 \\
\hline 7 & Fabbri soft serve Chocolate mix & 6,8 \\
\hline 8 & Pregel soft serve Chocolate mix & 6,7 \\
\hline 9 & Angelito Vanilla Flavour Dairy Ice Cream Mix & 6,4 \\
\hline 10 & Mondi ice-cream mix & 6,9 \\
\hline 11 & Pregel Yogursprint mix & 4,6 \\
\hline 12 & Pregel Yogursprint mix + fresh yogurt & 4,4 \\
\hline 13 & Yogurt mix & 5,1 \\
\hline 14 & Yogurt soft serve mix & 5,2 \\
\hline 15 & Orange based ice-cream mix & 3,5 \\
\hline 16 & Prickly pear based ice-cream mix & 6,2 \\
\hline 17 & Banana based ice-cream mix & 4,8 \\
\hline 18 & Strawberry based ice-cream mix & 3,6 \\
\hline 19 & Pear based ice-cream mix & 4,5 \\
\hline 20 & Kibana based ice-cream mix & 3,8 \\
\hline 21 & Lemon based ice-cream mix & 2,7 \\
\hline
\end{tabular}

405 Table 1 Ice-cream mixes tested in this work as well as measured values of $\mathrm{pH}$. 


\begin{tabular}{|c|c|c|c|c|c|c|c|}
\hline & \multicolumn{3}{|c|}{ SENSOR A } & \multicolumn{3}{|c|}{ SENSOR B } & \multirow[b]{2}{*}{ pH } \\
\hline & $\mathbf{R}_{\mathrm{m}}$ & $\mathbf{Q}$ & $\lambda$ & $\mathbf{R}_{\mathrm{m}}$ & $\mathbf{Q}$ & $\lambda$ & \\
\hline Milk based mixes/Fruit based mixes & $*$ & & $\mathrm{X}$ & * & & $\mathrm{X}$ & * \\
\hline Creamy mixes/Frozen Yogurt mixes & & * & & & * & & $\mathrm{X}$ \\
\hline
\end{tabular}

418

419 Table 2 Feasibility of ice-cream mixes discrimination based on the measures of electrical 420 parameters and $\mathrm{pH} . \mathrm{X}$ indicates that the corresponding parameter is suitable for the discrimination 421 of the corresponding groups. * indicates significantly different values between the two groups but 422 non reliable discrimination due to overlapping values. 
LCR meter Agilent E4980A

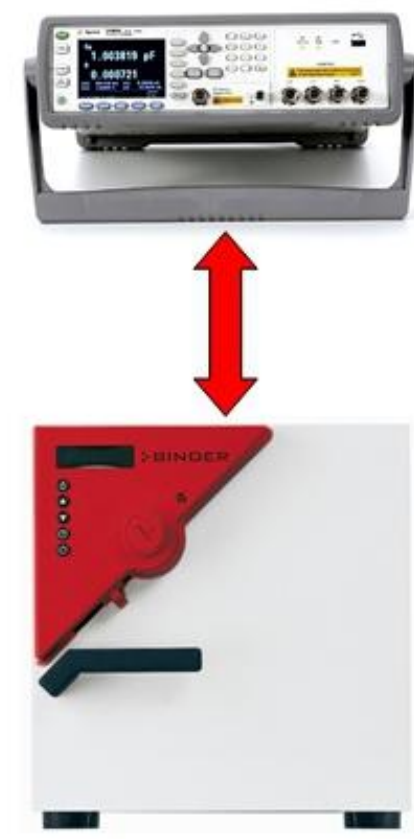

440

\section{Thermal incubator WTC Binder}
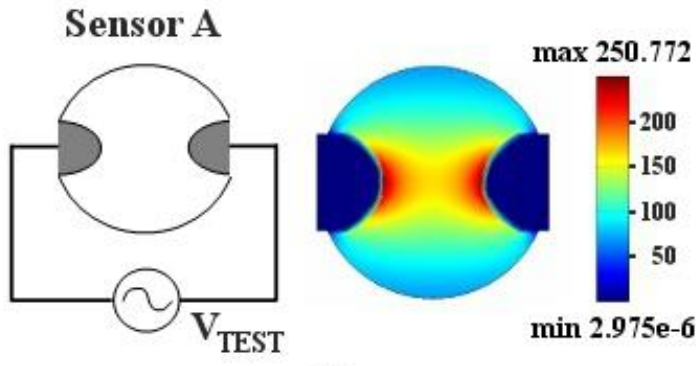

(b)

Sensor B
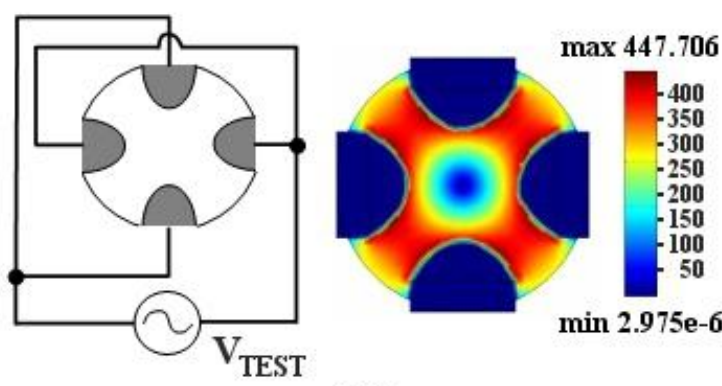

(c)

441 Fig. 1 Measurement setup used in the electrical characterization of ice-cream mixes (a). Geometries 442 and simulations of the generated electric field for sensor A (b) and sensor B (c). 

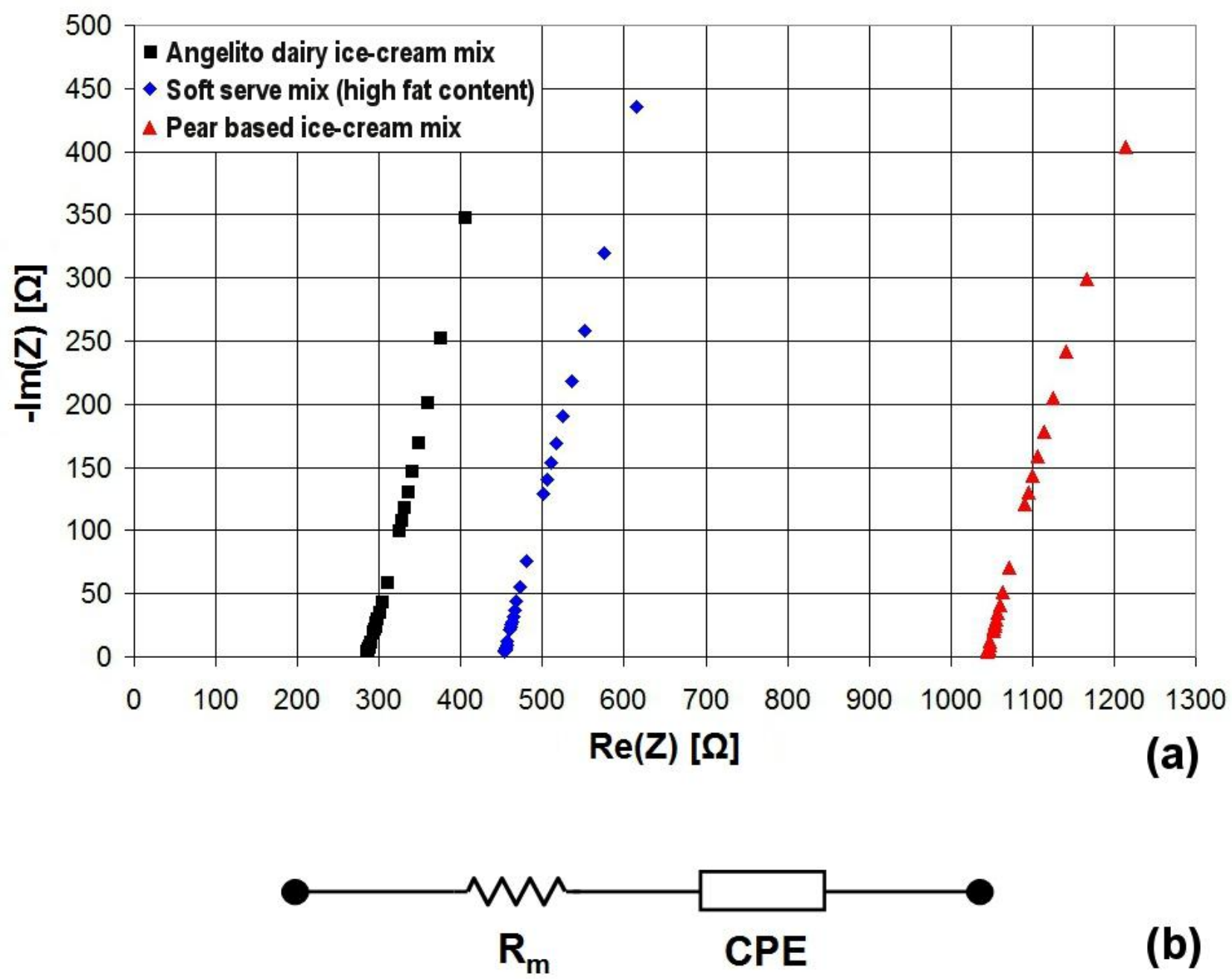

456 Fig. 2 Nyquist plot for three different ice-cream mixes (a) and electrical circuit used to model the 457 sensors electrical response (b). 

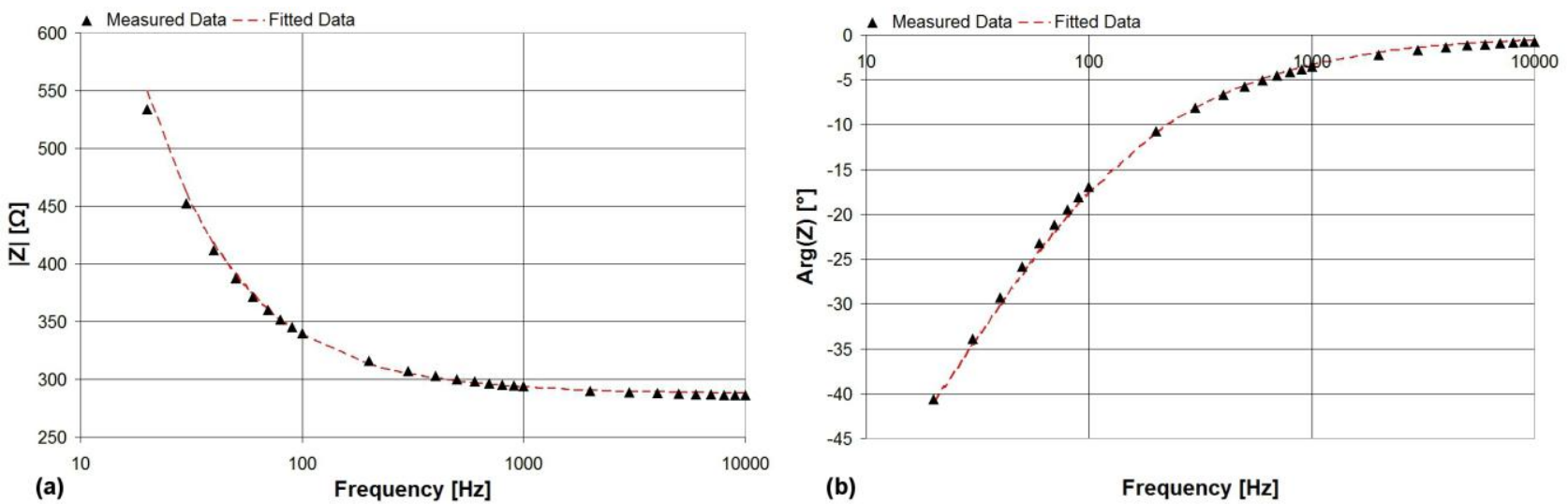

469 Fig. $3|Z|$ (a) and $\operatorname{Arg}(Z)$ (b) vs. frequency of the applied test signal for the Angelito mix (\# 9 in 470 Table 1) and sensor A. High correlation $\left(\mathrm{R}^{2}>0.998\right)$ is achieved for all ice-cream mixes and both 471 sensors between measured data and the electrical model of Fig. 2 (b). 


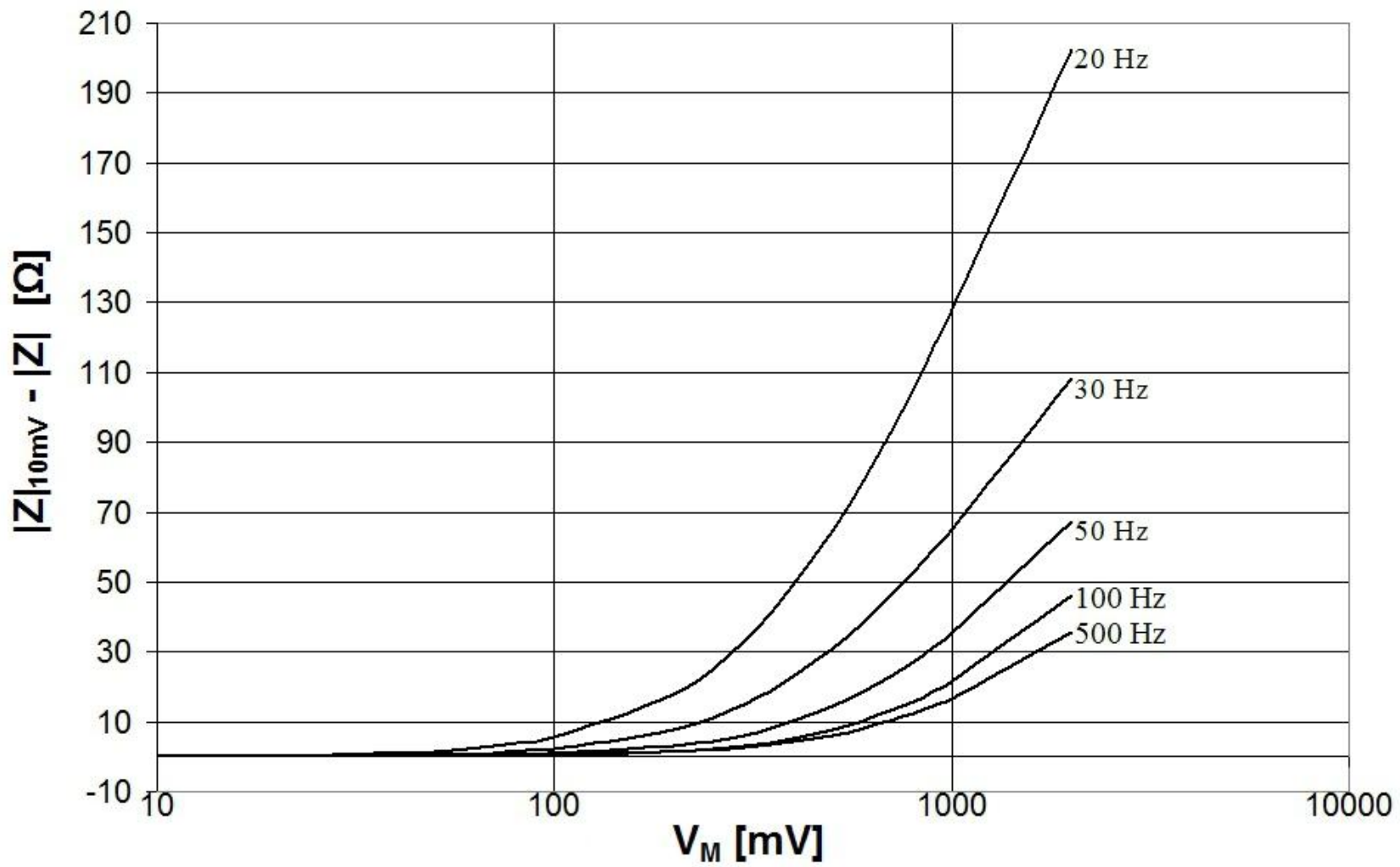

488 Fig. $4|\mathrm{Z}|_{10 \mathrm{mV}}-|\mathrm{Z}|$ vs. the amplitude $\mathrm{V}_{\mathrm{M}}$ of the applied test signal for different frequencies in the case of the Angelito mix (\# 9 in Table 1) and sensor A. Non-linear response is stronger at low 490 frequencies. 


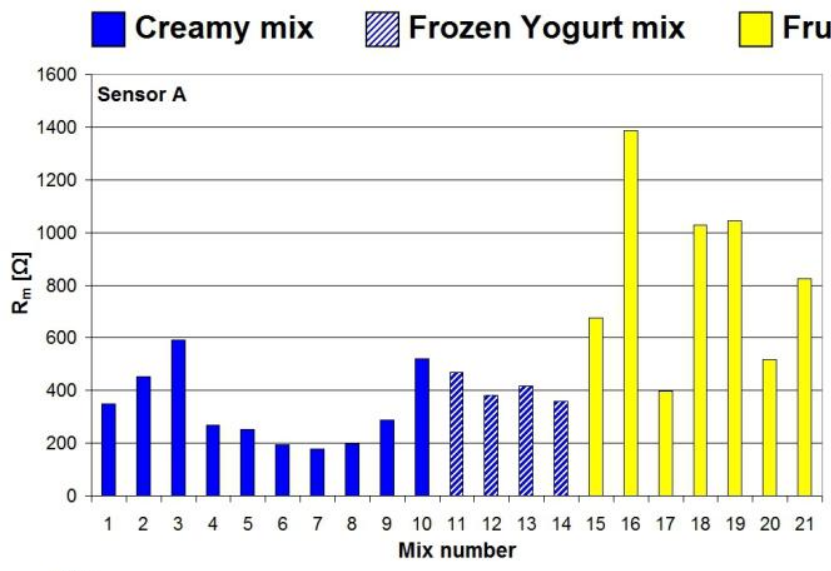

\section{ruit based mix}
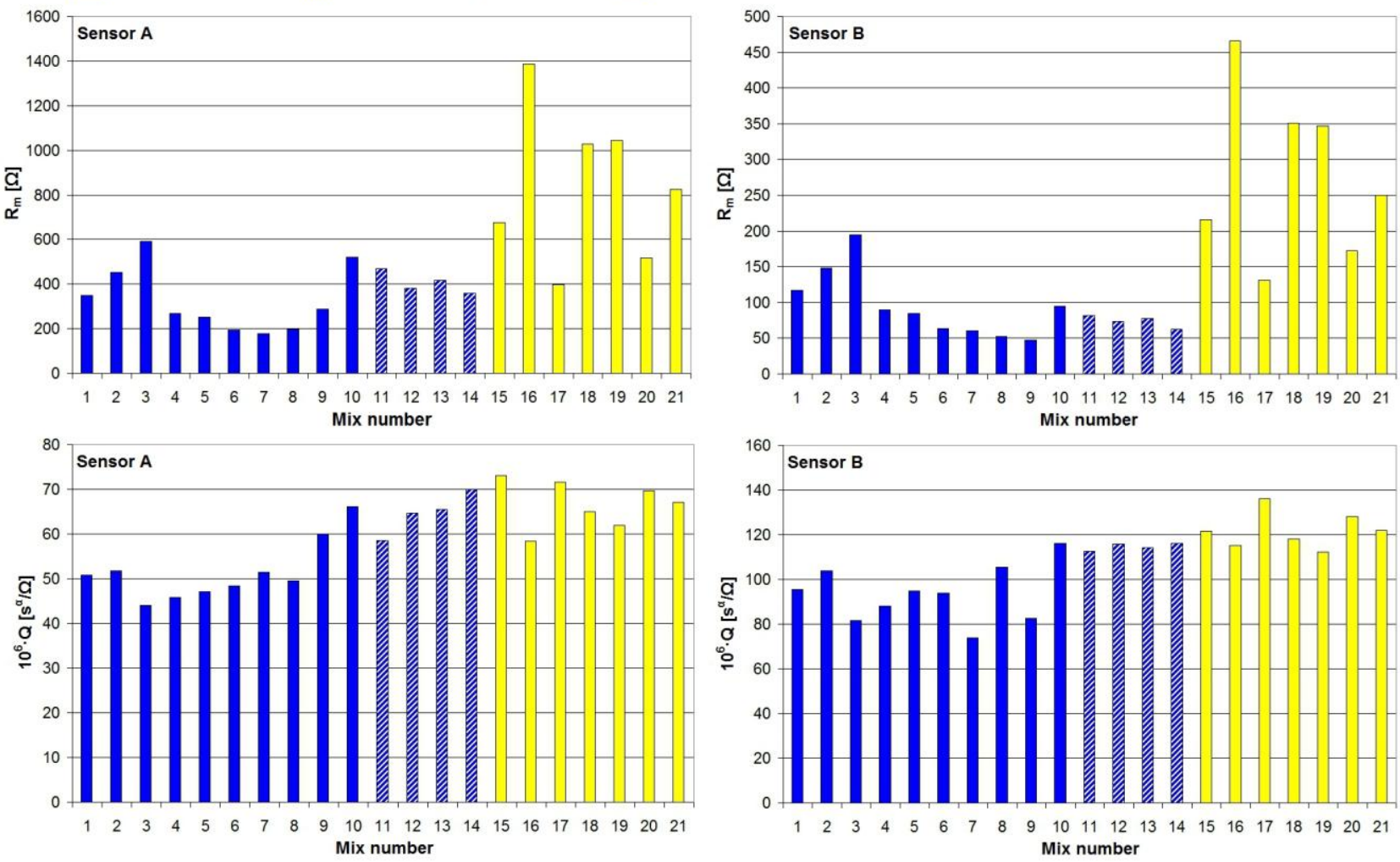

Fig. 5 Histograms of $R_{m}$ and $Q$ for all ice-cream mixes and both sensors used in this work. Creamy mixes bars are blue colored, frozen yogurt mixes are blue/white colored and fruit based ice-cream mixes are yellow colored. 


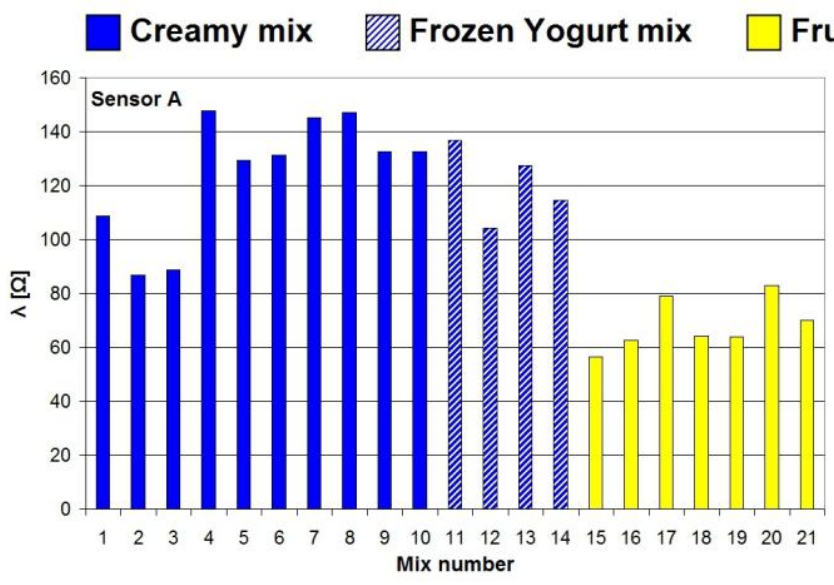

Fruit based mix

Fig. 6 Histograms of $\lambda$ for all ice-cream mixes and both sensors. Creamy mixes bars are blue colored, frozen yogurt mixes are blue/white colored and fruit based ice-cream mixes are yellow colored.

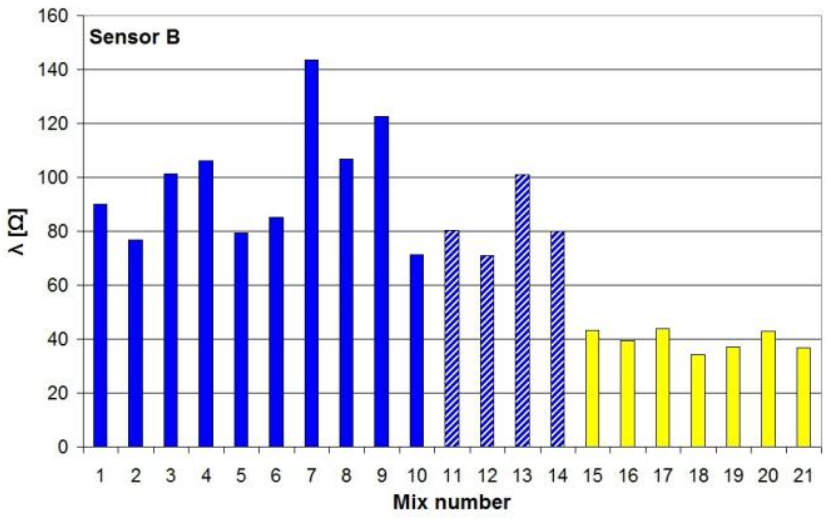




\section{Automatic Ice-Cream Characterization by Impedance Measurements for Optimal Machine Setting}

Marco Grossi, Massimo Lanzoni, Roberto Lazzarini, Bruno Riccò

\section{Ice-cream mixes}

Measurements have been performed on a set of 21 ice-cream mixes, different for ingredients and producers. In the following, the recipes for every mix used in the study are presented.

\begin{tabular}{|c|c|c|}
\hline \# & Ice-cream mix & $\begin{array}{ll}\text { Composition } \\
\end{array}$ \\
\hline 1 & Soft serve mix (low fat content - pasteurization at $65^{\circ} \mathrm{C}$ ) & $\begin{array}{l}\text { Water, Skimmed Milk Powder, Whipping Cream, Pregel Base Diamant } 100 \\
\text { and Sugar in the following composition: Sugar }(11.9 \%) \text {, Fat }(4 \%) \text {, Milk } \\
\text { Solids-nonfat }(8.9 \%) \text {, Stabilizers }(0.3 \%)\end{array}$ \\
\hline 2 & Soft serve mix (high fat content - pasteurization at $65^{\circ} \mathrm{C}$ ) & $\begin{array}{l}\text { Water, Skimmed Milk Powder, Whipping Cream, Pregel Base Diamant } 100 \\
\text { and Sugar in the following composition: Sugar }(17.2 \%) \text {, Fat (11.2\%), Milk } \\
\text { Solids-nonfat (12\%), Stabilizers }(0.3 \%)\end{array}$ \\
\hline 3 & Soft serve mix (high fat content - pasteurization at $85^{\circ} \mathrm{C}$ ) & $\begin{array}{l}\text { Water, Skimmed Milk Powder, Whipping Cream, Pregel Base Diamant } 100 \\
\text { and Sugar in the following composition: Sugar }(17.2 \%) \text {, Fat (11.2\%), Milk } \\
\text { Solids-nonfat (12\%), Stabilizers }(0.3 \%)\end{array}$ \\
\hline 4 & Egg based ice-cream mix & $\begin{array}{l}\text { Whole Milk (66.5\%), Skimmed Milk Powder (8\%), Fresh Whipping Cream } \\
\text { @ 35\% (8.2\%), Sucrose }(15.6 \%) \text {, Dextrose (2\%), Egg Yolk (7.5\%), Pregel } \\
\text { Base Diamant } 50(3.4 \%)\end{array}$ \\
\hline 5 & Fiordilatte ice-cream mix & $\begin{array}{l}\text { Whole Milk (70\%), Skimmed Milk Powder }(1, .3 \%) \text {, Fresh Whipping Cream } \\
@ 35 \%(8.2 \%) \text {, Sucrose }(15.4 \%) \text {, Dextrose }(1.7 \%) \text {, Pregel Base Diamant } 50 \\
(3.4 \%)\end{array}$ \\
\hline 6 & Chocolate ice-cream mix & $\begin{array}{l}\text { Whole Milk (63\%), Fresh Whipping Cream @ 35\% (10\%), Sucrose (15.6\%), } \\
\text { Dextrose (2\%), Cocoa Powder (24\%), Pregel Base Diamant } 50(3.4 \%)\end{array}$ \\
\hline 7 & Fabbri soft serve Chocolate mix & $\begin{array}{l}\text { Sugar, Cocoa Powder, Whole Milk Powder, Skimmed Milk Powder, } \\
\text { Maltodextrins, Stabilisers (E412, E466), Emulsifiers (E471), Flavouring in } \\
\text { the following composition: } 2.25 \text { liters by water and } 1 \mathrm{Kg} \text { by powder }\end{array}$ \\
\hline 8 & Pregel soft serve Chocolate mix & $\begin{array}{l}\text { Sugar, Cocoa Powder, Skimmed Milk Powder, Hydrogenated Vegetable Fat, } \\
\text { Dextrose, Dehydrated Glucose Syrup, Stabilisers (E412, E410, E466), } \\
\text { Emulsifiers (E471,E472a, E472b), Acidifier (E330) }\end{array}$ \\
\hline 9 & Angelito Vanilla Flavour Dairy Ice Cream Mix & $\begin{array}{l}\text { Skimmed Milk, Sugar, Butter, Skimmed Milk Powder, Dried Glucose, Syrup, } \\
\text { Emulsifiers (E477, E471), Stabilisers (E466, E412, E407, E451), Flavouring }\end{array}$ \\
\hline 10 & Mondi ice-cream mix & $\begin{array}{l}\text { Sugar, Coconut Oil, Dextrose, Glucose Powder, Milk Proteins, Stabilisers } \\
\text { (E412, E410, E466), Emulsifiers (E471, E473), Flavouring in the following } \\
\text { composition: } 17.5 \mathrm{Kg} \text { by powder and } 30 \text { liters by water }\end{array}$ \\
\hline 11 & Pregel Yogursprint mix & $\begin{array}{l}\text { Sugar, Dextrose, Skimmed Milk Powder, Skimmed Yogurt Powder, } \\
\text { Maltodextrins, Acidifier (E330), Flavouring, Hydrogenated Vegetable Fat, } \\
\text { Stabilisers (E412, E410, E466), Emulsifiers (E471,E472a, E472b, E477) in } \\
\text { the following composition: } 2.5 \text { liters by Whole Milk and } 1 \mathrm{Kg} \text { by powder }\end{array}$ \\
\hline 12 & Pregel Yogursprint mix + fresh yogurt & $\begin{array}{l}\text { Sugar, Dextrose, Skimmed Milk Powder, Skimmed Yogurt Powder, } \\
\text { Maltodextrins, Acidifier (E330), Flavouring, Hydrogenated Vegetable Fat, } \\
\text { Stabilisers (E412, E410, E466), Emulsifiers (E471,E472a, E472b, E477) in } \\
\text { the following composition: } 2 \text { liters by Whole Milk, } 500 \mathrm{~g} \text { by Fresh Skimmed } \\
\text { Yogurt and } 1 \mathrm{Kg} \text { by powder }\end{array}$ \\
\hline 13 & Yogurt mix & $\begin{array}{l}\text { Skimmed Yogurt (2 liters), White Base (1 liters), Sucrose }(450 \mathrm{gr}) \text {, Skim } \\
\text { Solids }(8 \mathrm{gr}) \text { with White Base in the following composition: Milk (1 liters), } \\
\text { Skimmed Milk Powder }(50 \mathrm{gr}) \text {, Whipping Cream }(258 \text { gr), Sucrose }(250 \mathrm{gr}) \text {, } \\
\text { Dextrose }(25 \mathrm{gr}) \text {, Glucose }(33 \mathrm{gr}) \text {, Skim Solids }(8 \mathrm{gr}) \text {, Proteins }(25 \mathrm{gr})\end{array}$ \\
\hline 14 & Yogurt soft serve mix & $\begin{array}{l}\text { Whole Milk ( } 482 \text { gr), Skimmed Yogurt }(300 \mathrm{gr}) \text { and Yosoft Powder }(220 \mathrm{gr}) \\
\text { with the following ingredients: Sucrose, Vegetable Fiber, Skimmed Milk } \\
\text { Powder, Skimmed Yogurt Powder, Dextrose, Emulsifiers (E471, E472b, } \\
\text { E472, E477), Acidifier (E330), Stabilisers (E410), Flavouring }\end{array}$ \\
\hline 15 & Orange based ice-cream mix & $\begin{array}{l}\text { Orange }(69.3 \%) \text {, Water }(4.9 \%) \text {, Sugar }(20.8 \%) \text {, Fruit Base } 50(3.5 \%) \text {, Lemon } \\
\text { Juice }(1.5 \%)\end{array}$ \\
\hline 16 & Prickly pear based ice-cream mix & $\begin{array}{l}\text { Prickly Pear }(50 \%) \text {, Water }(25.5 \%) \text {, Sugar (22\%), Fruit Base } 50(2.5 \%) \text {, } \\
\text { Lemon Juice }(1.5 \%)\end{array}$ \\
\hline 17 & Banana based ice-cream mix & $\begin{array}{l}\text { Banana }(50 \%) \text {, Water }(27.6 \%) \text {, Sugar }(20.4 \%) \text {, Fruit Base } 50(2 \%) \text {, Lemon } \\
\text { Juice }(1.5 \%)\end{array}$ \\
\hline 18 & Strawberry based ice-cream mix & $\begin{array}{l}\text { Strawberry }(50 \%) \text {, Water }(23,5 \%) \text {, Sugar }(24 \%) \text {, Fruit Base } 50(2.5 \%) \text {, } \\
\text { Lemon Juice }(1.5 \%)\end{array}$ \\
\hline 19 & Pear based ice-cream mix & $\begin{array}{l}\text { Pear }(50 \%) \text {, Water }(25 \%) \text {, Sugar }(22.5 \%) \text {, Fruit Base } 50(2.5 \%) \text {, Lemon } \\
\text { Juice }(1.5 \%)\end{array}$ \\
\hline 20 & Kibana based ice-cream mix & $\begin{array}{l}\text { Kiwi }(35 \%) \text {, Banana }(15 \%) \text {, Water }(24.9 \%) \text {, Sugar }(23 \%) \text {, Fruit Base } 50 \\
(2.1 \%) \text {, Lemon Juice }(1.5 \%)\end{array}$ \\
\hline 21 & Lemon based ice-cream mix & $\begin{array}{l}\text { Lemon Mashed Fruit Pulp (69.3\%), Water (4.9\%), Sugar (20.8\%), Fruit Base } \\
50(3.5 \%) \text {, Lemon Juice }(1.5 \%)\end{array}$ \\
\hline
\end{tabular}




\section{Electrical characterization in the frequency range $20 \mathrm{~Hz}$ to $2 \mathrm{MHz}$}

Preliminary measurements have been carried out on a limited number of ice-cream mixes using a sinusoidal test signal of amplitude $100 \mathrm{mV}$ and frequency in the range $20 \mathrm{~Hz}$ to $2 \mathrm{MHz}$ for the incubation temperature of $35{ }^{\circ} \mathrm{C}$. The Nyquist plot for the entire frequency range as well as a particular of the higher frequencies are shown in Fig. S1 for mix \# 2 and sensor A (different mixes and sensor B result in similar behavior).
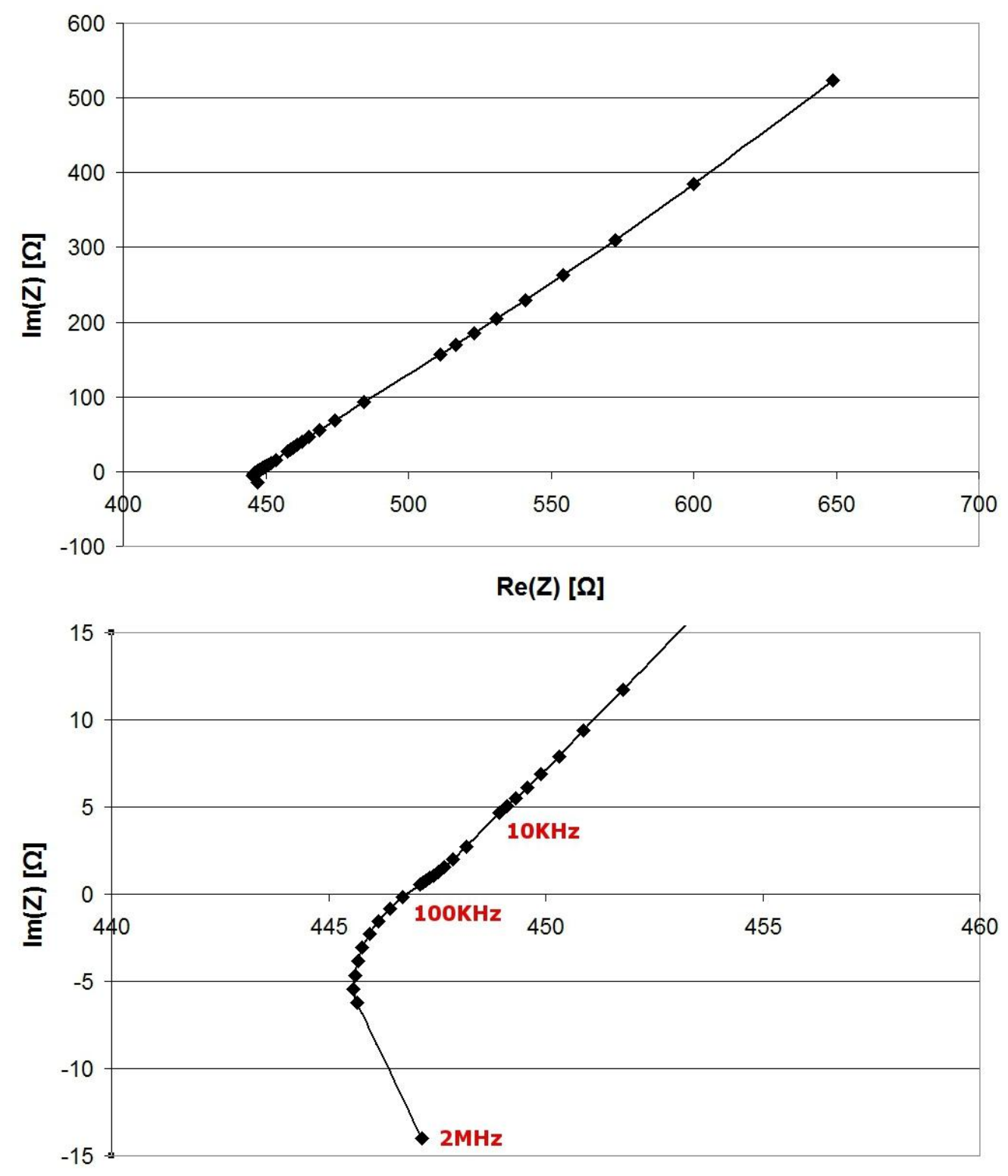

\section{$\operatorname{Re}(\mathbf{z})[\Omega]$}

Fig. S1 Nyquist plot in the frequency range $20 \mathrm{~Hz}$ to $2 \mathrm{MHz}$ for mix \# 2 and sensor $\mathrm{A}$ at $35^{\circ} \mathrm{C}$.

The results from Fig. S1 clearly indicates that the electrical model featuring a resistance $\left(\mathrm{R}_{\mathrm{m}}\right)$ and a CPE (Q) in series is adequate for frequencies up to $400 \mathrm{kHz}$. For higher frequencies a deviation from the model occours. The real component of the impedance $\operatorname{Re}(\mathrm{Z})$ was almost the same at 10 $\mathrm{kHz}$ and $2 \mathrm{MHz}$ (differences lower than 0.2\%). Repeated measures on the same ice-cream mix (\# 2) were carried out to test the repeatability of the measures. The results show that $\operatorname{Re}(Z)$ results in comparable repeatability at $10 \mathrm{kHz}$ and $2 \mathrm{MHz}$ (with a ratio of standard deviation to mean value $\sigma / \mu$ of 0.03 ), while the imaginary component $\operatorname{Im}(Z)$ resulted in higher dispersion at higher frequency (with a $\sigma / \mu$ value of 0.19 at $2 \mathrm{MHz}$ almost twice than at $10 \mathrm{kHz}$ ). The higher dispersion at higher frequencies can be related to some parasistic effects in the sensor that have to be further 
investigated. Since the less repeatability of the measures and the fact that, from preliminary measurements, data on the extended frequency range don't provide further informations, the investigated frequencies in the paper has been limited to the range $20 \mathrm{~Hz}$ to $10 \mathrm{kHz}$.

\section{Measurements at $4^{\circ} \mathrm{C}$ and $35^{\circ} \mathrm{C}$ : results comparison}

Mix \# 2 from Table 1 in the paper has been analyzed in triplicate using EIS with a sinusoidal test voltage of amplitude $100 \mathrm{mV}$ and frequency range from $20 \mathrm{~Hz}$ to $10 \mathrm{kHz}$ with both sensors. In Fig. $\mathrm{S} 2$ the Nyquist plot is shown for the three measures at both temperatures of $4{ }^{\circ} \mathrm{C}$ and $35{ }^{\circ} \mathrm{C}$ for sensor A. Measures at $4{ }^{\circ} \mathrm{C}$ resulted in less repeatability than $35^{\circ} \mathrm{C}$. This can be related to the fact that at $4{ }^{\circ} \mathrm{C}$ the ice-cream mixes are in a semi viscous frozen state and also small temperature variations can produce relatively large changes in the product structure.

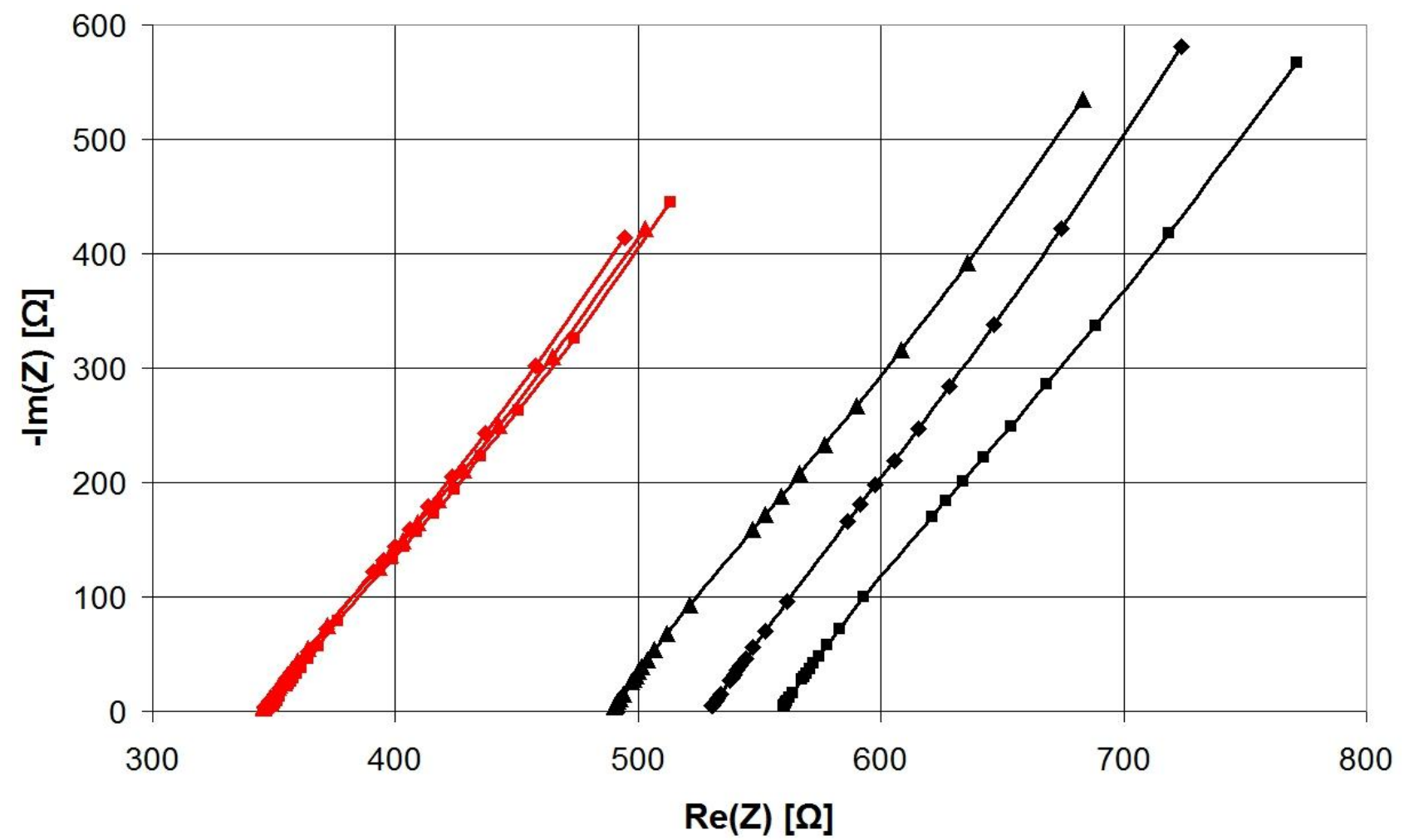

Fig. S2 Nyquist plot in the frequency range $20 \mathrm{~Hz}$ to $10 \mathrm{kHz}$ for mix \# 2 (measures in triplicate) and sensor $\mathrm{A}$ at two different incubation temperatures: $4{ }^{\circ} \mathrm{C}$ and $35^{\circ} \mathrm{C}$.

Statistical analysis has been carried out and mean value $\mu$ as well as the ratio of standard deviation to mean value $\sigma / \mu$ have been calculated for both sensors and temperatures. The results are presented in the following table.

SENSOR A

\begin{tabular}{|c|c|c|c|c|c|}
\hline & & $\mathrm{T}=4^{\circ} \mathrm{C}$ & $\mathrm{T}=35^{\circ} \mathrm{C}$ & $\mathrm{T}=4{ }^{\circ} \mathrm{C}$ & $\mathrm{T}=35^{\circ} \mathrm{C}$ \\
\hline \multirow{2}{*}{$\mathrm{R}_{\mathrm{m}}$} & $\mu[\Omega]$ & 524.7 & 345.5 & 186 & 116.7 \\
\hline & $\sigma / \mu$ & 0.066 & 0.005 & 0.055 & 0.005 \\
\hline \multirow{2}{*}{$\mathrm{Q}$} & $\mu\left[10^{6} \mathrm{~s}^{\alpha} / \Omega\right]$ & 38.7 & 52.7 & 71.3 & 86.7 \\
\hline & $\sigma / \mu$ & 0.08 & 0.03 & 0.18 & 0.09 \\
\hline
\end{tabular}


The correlation between measured electrical parameters $\mathrm{R}_{\mathrm{m}}, \mathrm{Q}$ and $\lambda$ for both type of sensors and $\mathrm{pH}$ has been investigated, and the results are presented in Fig. S3, where the values of $\mathrm{pH}$ are plotted versus the corresponding electrical parameter for all products tested and both sensors.

592
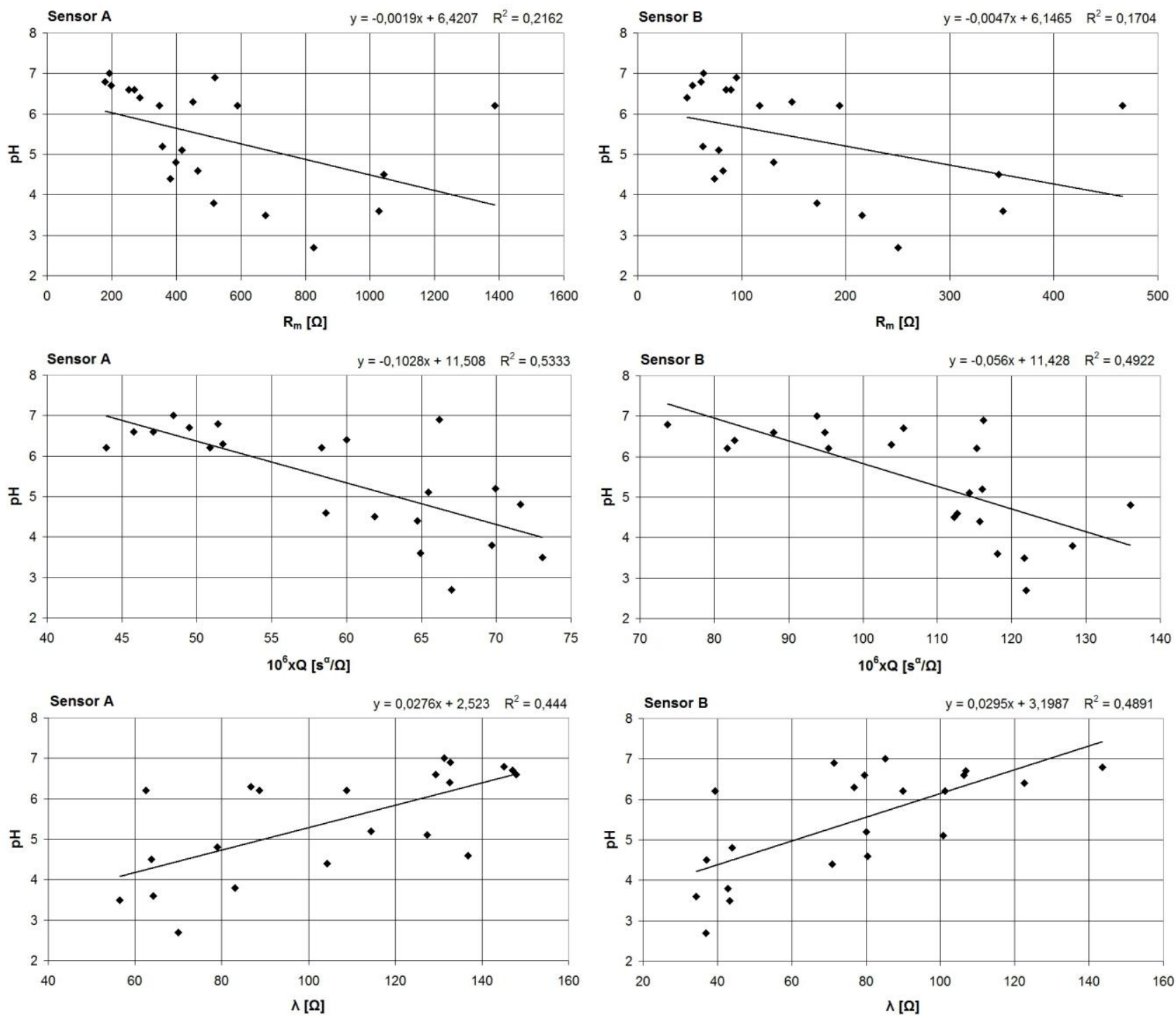

Fig. S3 Scatter plots of $\mathrm{pH}$ values vs. $\mathrm{R}_{\mathrm{m}}, \mathrm{Q}$ and $\lambda$ for all tested mixes and both sensors. Linear regression lines as well as determination coefficient $R^{2}$ have been calculated. 